\title{
STUDENTS ATTITUDES REGARDING THE ETHICS OF EARNINGS MANAGEMENT ACTIVITIES: AN EMPIRICAL INVESTIGATION
}

\author{
Dan Dacian Cuzdriorean ${ }^{1}$
}

\begin{abstract}
The objective of this paper is to assess the ethics of short-term earnings management in a code-law country. In order to understand the morals of short-term earnings management we conducted a survey using students as respondents. Even if we found disagreement among our respondents, the findings of this study document that ethical acceptance of short-term earnings management depends on the type of manipulation (e.g. accrual-based earnings management versus real earnings management). Also, the results indicate that students with higher moral development evaluate short-term earnings management practices as less ethical and are less likely to accept it. The paper concludes with a discussion of the implications and suggestions for future research.
\end{abstract}

Keywords: ethical judgments, accrual based earnings management, real earnings management

JEL Codes: I21, I23, M12, M14, M40, M41

\section{Introduction}

The acceptability of the practices of earnings management is an important topic in accounting and management field (Johnson et al., 2012). Moreover, earnings management practices are the main ones raising suspicion about accountants and managers' integrity (Fisher and Rosenzweig, 1995).

Beginning with the first study conducted by Bruns and Merchant (1990), unfavorable results were documented in terms of moral behavior of business participants. The results of the previous studies documented that managers are convinced that if a practice is not explicitly prohibited or there is a minor deviation from the accounting rules, it becomes an ethical practice regardless of who might be affected by the practice or by information that flows from it (Bruns and Merchant, 1990).

In this respect the main concern is related to the miss-specification of earnings information since those can be manipulated (Trompeter et al., 2013). In the light of previous accounting scandals and decreasing credibility in the accounting profession, leading accounting associations, since 1990s, have called for increased emphasis on ethics (Wesley and Ndofor, 2013). Given the inherent discretion in accounting that managers and practitioners must exercise, it is desirable for them to have knowledge and of ethical sensitivity regarding earnings management practices (Fisher and Rosenzweig, 1995).

This particular study is part of this trend, since its goal is given by the assessment of ethical perceptions of accounting students related to short-term earnings management practices in a codelaw country.

The subject is timely and relevant at least for two reasons. First, earnings management practices spring an increased interest in the light of previous accounting scandals, responsible for the major losses suffered by innocent people. Second, public confidence in accounting profession is the main roots that maintain this profession alive. Therefore, in order for audit and accounting to survive is necessary to act ethically and responsible (Arel et al., 2012).

\footnotetext{
${ }^{1}$ Babeş-Bolyai University, Cluj-Napoca, Romania,e-mail:dan.cuzdriorean@econ.ubbcluj.ro
} 
Since the negative consequences attached, ethical values emphasis increased over time. Thus, the examination of the ethical acceptability of earnings management deserves continuing attention. Since most of the empirical studies to date assessing the ethical acceptance of students regarding earnings management practices, assessed students from western cultures such as USA and UK, the present study has the potential to fill a gap in the literature. Also, this potential is given by the fact that respondents are located in a code-law country (e.g. Spain), which are known by their high tolerance in terms of earnings management (Leuz et al., 2003).

The remainder of this paper is organized as follows. The first segment comprises the research problem and purpose of the study. The next section provides a review of the relevant literature, followed by the methodology and research design. The findings and discussion segment includes the analysis of the survey conducted. The conclusion, limitation and scope for future research segment are the latter approached.

\section{The research problem and purpose of the study}

The problems that spring from with earnings management practices rely in the consequences attached to the existence and magnitude of those practices. Having mainly a negative side, earnings management activity is costly in terms of misallocation of resources. Anyone who is using short term earnings information can be deceived by manipulation in cases where some practices used by managers are unethical (Choi, 2012).

Dealing with the ethical perceptions of accounting students towards earnings management activity acceptance, this particular study represents one step toward a more refined understand of individual ethical judgments. The purpose of this study is to investigate, in an empirical setting, the degree of acceptance of earnings management activities.

\section{Background and hypothesis}

Despite the growing interest, the empirical results found in the literature concerning ethical judgments and earnings management acceptance document both inconsistent and contradictory results. On the other hand, the acceptance of earnings management practices raises the most important and controversial ethical issues in the accounting profession (Johnson et al., 2012). To help resolve those issues, this particular study explores empirically and evaluates the predisposition for ethical judgments and behavioral intentions of accounting students.

The ethicalness of earnings management was examined in previous studies with mix results (Bruns and Merchant, 1990; Merchant and Rockness, 1994; Fisher and Rosenzweig, 1995; Clikeman et al., 2001; Jooste, 2011; Johnson et al., 2012). Based on the previous evidence it seems that ethics is overridden by the opportunistic behavior (Wesley and Ndofor, 2013). Also, it seems that individual differences in making ethical decisions do exist and those came either from national origin either gender (Clikeman et al., 2001).

Since some of the earnings management practices can be immoral and unethical (Bruns and Merchant, 1990), the public confidence in accounting profession have been shaken seriously (Trompeter et al., 2013).

Earnings management practices include accounting-based activities or real earnings management. Fisher and Rosenzweig (1995) approaching the accrual-based earnings management, gave as example the adjusting the amounts of the reserves, thereby changing reported income. For real earnings management, the same authors offered as example the timing of transactions.

To summarize, ethical perspective raised multiple questions over time. Combined with the acceptance or limiting earnings management activities gave rise to even more complex questions. In this study is trying to extend previous cited sources by examining Spanish students' perceptions of the ethical acceptance of earnings management. No surveys using the Bruns and Merchant (1990) questionnaire are available in Spain. Therefore, the results obtained can be compared with other available studies in the literature. 
Taking into account the preceding discussion, students' perceptions regarding earnings management ethicality can vary. Given the cultural differences, the hypothesis (null) tested in this paper is:

H: There is no difference in perceptions of the ethical acceptability of earnings management for students from Spanish economic environment.

\section{Methodology}

In order to measure the ethical perception of earnings management practices, a survey was conducted. In order to conduct it, a restricted form of questionnaire was used. Since the goal was to extend the literature, the questionnaire used was the one developed by Bruns and Merchant (1990). The main argument for choosing this particular questionnaire consisted in the fact that it was extensively used in previous similar studies (Clikeman et al., 2001; Rosenzweig and Fisher, 1994; Fisher and Rosenzweig, 1996; Merchant and Rockness, 2011; Jooste, 2011). In order to be able to compare our results to similar studies conducted in the literature, a similar path and instrument of research was chosen.

All the participants of the study were tested in the same time and location, having the same age and the same unit specialization. The language used was English. No translation was necessary since respondents' line of study was English.

\section{Research design}

This descriptive study comprised a survey testing using accounting students as participants. Students were chosen since they tend to give us a generalized understanding on how the general business public accepts such manipulations. Moreover, we opted for accounting students given the technical nature of the scenarios comprised.

Data was collected by means of one restricted form questionnaire, administrated to the respondents with the goal of examining the ethical acceptance of earnings management practices. The questionnaire comprised 13 practices, including both accrual-based earnings management and real earnings management. The practices included are considered short-term earnings management activities.

\section{Sample}

Only one group was surveyed, comprising under-graduating last year accounting students from one of the largest public university in Spain, in 2013 as year of examination. Participation was voluntary and the responses to the questionnaires were anonymous. The students ranged in age from 21 to 32 years with a median age of 23 years.

Three students did not answer all the questions, resulting in 57 usable responses. From the students participating, 27 were female. All students were residing in their home country.

There were no significant differences between our participants in terms on accounting course hours or ethics course hours and the participants from previous studies conducted in the literature, using students as respondents.

\section{The questionnaire}

For assessing the ethical acceptability of earnings management practices, the questionnaire developed by Bruns and Merchant (1990) was used as it was stated earlier. Our participants were informed that the questionnaire refers to $\$ 1$ billion Company consisting of different divisions which has a January-December fiscal year. Similar to Bruns and Merchant (1990) explanations were given that each division has a turnover of $\$ 100$ million and net profits before taxation of $\$ 12$ million. We asked our participants to rate each of the 13 short-term earnings management practices using a fivepoint Likert scale as following: 
$1=$ Ethical practices (mean below 1,5);

$2=$ Questionable practice. I would not say anything to the person involved but it makes me uncomfortable (mean between 1,5 and 2,5);

$3=$ Minor practice. The person should be warned not to engage in the practice again (mean between 2,5 and 3,5);

$4=$ Serious infraction. The person should be severely reprimanded (mean between 3,5 and $4,5)$

$5=$ Totally unethical. The person should be fired (mean between 4,5 and 5).

High scores correspond with higher degrees of ethical unacceptability.

On the first page of the second questionnaire, similar to Burns and Merchant (1990) it was specified that the questionnaire consist in a short description of a variety of actions that individuals have taken. Some of the actions are ethical, while others are considered by the most people as being unethical. Since above previous studies documented that judgments as to the degree of severity of the infraction may vary in space and time, our participants were asked to assess each of the scenarios in terms of ethical acceptance.

\section{Findings and discussion}

Accordingly, Table no. 1 reports the mean values for acceptance scores of earnings management practices in our sample. The table below also comprises the mean values of previous studies for comparison purposes.

Mean values of short-term earnings management practices

\begin{tabular}{|c|c|c|c|}
\hline No. & $\begin{array}{c}\text { Description of the short-term earnings management } \\
\text { practices }\end{array}$ & $\begin{array}{l}\text { Mean } \\
\text { values }\end{array}$ & $\begin{array}{c}\text { Prior } \\
\text { studies* }\end{array}$ \\
\hline 1 & Paint ahead of schedule & 1,95 & 1,32 \\
\hline 2 & Defer discretionary expenses to meet quarterly budget & 2,46 & 2,24 \\
\hline 3 & Defer discretionary expenses to meet annual budget & 2,05 & 2,60 \\
\hline 4 & Defer suppliers expenses to delaying recording invoice & 2,56 & 3,30 \\
\hline 5 & Credit that has more liberal terms to reach budget target & 2,42 & 2,04 \\
\hline 6 & Work overtime to reach budget target & 2,00 & 1,66 \\
\hline 7 & Sell excess assets to reach budget target & 2,44 & 1,61 \\
\hline 8 & Prepay expenses to reduce income by $\$ 60000$ & 3,37 & 3,03 \\
\hline 9 & $\begin{array}{l}\text { Increase reserves for inventory obsolescence, reduce } \\
\text { income } \$ 700000\end{array}$ & 2,91 & 3,26 \\
\hline 10 & $\begin{array}{l}\text { Decrease reserves for inventory obsolescence to } \\
\text { continue work }\end{array}$ & 3,07 & 3,15 \\
\hline 11 & $\begin{array}{l}\text { Reduce reserve for inventory obsolescence to meet } \\
\text { budget target }\end{array}$ & 3,21 & 3,34 \\
\hline 12 & Request deferred billing to suppliers $\$ 30000$ & 3,05 & 3,17 \\
\hline 13 & Request deferred billing from suppliers $\$ 500000$ & 3,40 & 3,89 \\
\hline & Average rating for study overall & 2,76 & 2,66 \\
\hline
\end{tabular}

*The mean values of prior studies are presented in Annex no. 1. Those mean values were calculated by the author based on the results presented in the studies approached.

Source: Author's projection

The mean values presented in Table 1 are above the average of the prior studies for six of the 13 scenarios described $(1,2,5,6,7$ and 8). This indicates that the participants opinions are stricter compared with previous respondents for those particular practices. In seven of the 13 practices described (e.g. 3, 4, 9, 10, 11, 12 and 13), the respondents from previous studies had 
stricter views. The greater difference in the mean value is 0.83 (scenario 7 , mean 2,44) and the smallest difference is 0.08 (scenario 10, mean 3,07). The overall average for all 13 practices assessed in this particular study was 2,76 which is 0,10 higher that overall average of the prior studies.

The overall responses showed a significant lack of agreement and the dispersion of ratings was great. In this respect the results obtained are documenting a striking lack of agreement, since none of the participants viewed any of the 13 practices unanimously as an ethical or unethical practice.

The average responses documented that none of the 13 practices are considered ethical by our participants (mean below 1,5). Students had the least objection to the practice of painting ahead of schedule (scenario 1; mean 1,95) similarly to previous results documented in the literature (Clikeman et al., 2001).

On average, similarly to Bruns and Merchant (1990) the participants in this particular study regarded accrual-based earnings management less acceptable than real earnings management practices. Based on those results it can be accepted that the method of earnings management do matters in terms of ethical acceptability. From the 13 practices examined, six are rated as moderate as ethical acceptance, all six being real earnings management scenarios (1, 2, 3, 5, 6 and 7).

A review of the responses to the individual cases indicates that the students participating in this study objected more strongly to accrual based earnings management compared to real earnings management, similarly to previous results documented in the literature (Clikeman et al., 2001; Merchant and Rockness, 1994).

This particular study found no evidence that gender significantly affects judgments about the ethical acceptability of earnings management practices. Similarly to Clikeman et al. (2001), female and male students perceived the ethical practices in the same way. This can be explained based on the fact that the scenarios used do not have an explicit interpersonal component.

\section{Conclusion, limitations and scope for future research}

Short term earnings management practices it seems to be frequent if we were to take into account the existence of previous accounting scandals. Similarly to Bruns and Merchant (1990) the author believes that people engaging in immoral or unethical practices have an incomplete understanding of the implications of their practices.

Main findings of this study documents large tolerance for real earnings management practices comparing to accrual-based earnings management and dispersion of participants views about what practices are moral and ethical. In the view of the author this can be explained by the fact that students were making their judgments using a legalistic view of ethics. The author believes that this disagreement exists beyond this empirical study, in corporations where managers deal with the inability to agree on the types of earnings management practices that are acceptable. Second finding can be explained by using the view of Des Jardins and McCall (1990) who asserted that in ethical-decision making there is an inherent ambiguity. They argued that ethical principles or rules have limited applicability, ethics being a matter of "practical wisdom". Since there is empirical support for the efficacy of education in increasing cognitive abilities in making moral judgments (Rest, 1986), it is accepted that an increase emphasis on ethics should be the main goal of business curricula.

Thus, the overall results add support to the body of literature that students ethical judgments of ethical acceptability of earnings management depend on the type of manipulation and by bringing more empirical evidence regarding the considerably variation of judgments regarding short-term earnings management acceptance.

The results of this particular study should be treated with caution since the sample comprised accounting students. Based on the fact that students have fewer risks than business managers for instance maybe they tend to judge the scenarios proposed differently. Also, there is a 
small possibility that some of the students may not fully understand the wording of the questionnaire on earnings management or the scenarios comprised. Since the type of the questionnaire was restricted there is not certain that some of the results are not hypothetical. In this respect is possible for some results to be simply hypothetical since there is the possibility that students didn't recognize that they can manage earnings. On the other hand there is also a higher probability that students do recognize that they are doing earnings management and simply chose to do it.

The personal traits of the participants did not differ across the group surveyed, so this item cannot be made responsible for the results obtained. A neutral language was used, so there is no evidence that the respondents could answer the way they did. The results obtained are similar with previous empirical studies conducted even if the respondents comprised in this study were students and not practitioners.

Future research should attempt to identify specific situations that can lead to different ethical decisions in a business context. Also, future research can try to foster the role of personal values in accounting and the examination of intervention methods role in changing students' personal values toward a desired goal. Since the students are the future business participants, a demarche like this one can be useful. A third future direction should examine the way corporate culture can impact short-term earnings management, in terms of supporting the widespread use of immoral earnings management.

\section{References}

1. Arel B., Beaudoin C., Cianci A., 2012. The Impact of Ethical Leadership, the Internal Audit Function and Moral Intensity on a Financial Reporting Decision, Journal of Business Ethics, volume 109, issue 3, pp. 351-366

2. Bruns W.J., Merchant K.A., 1990. The Dangerous Morality of Managing Earnings, Management Accounting, volume 72, issue 2, pp. 22-25

3. Choi T., 2012. Do Ethical Companies Have Lower Implied Cost of Equity Capital? Evidence from Korean Stock Market, Asian Business and Management, volume 11, issue 2, pp. 219-246

4. Clikeman P., Greiger M., O`Connell B., 2001. Student Perceptions of Earnings Management: The Effects of National Origin and Gender, Teaching Business Ethics, volume 5, issue 4, pp. 389-410

5. DesJardins J.R., McCall J.J., 1990. Virtues and Business Ethics, Contemporary Issues In Business Ethics, $2^{\text {nd }}$ Edition, Wadsworth Pub. Co., Belmont, pp. 54-59

6. Fischer M., Rosenzweig K., 1995. Attitudes of Students and Accounting Practitioners Concerning the Ethical Acceptability of Earnings Management, Journal of Business Ethics, volume 14, issue 6, pp. 433-444

7. Johnson E., Fleischman G., Valentine S., Walker K., 2012. Managers`Ethical Evaluations of Earnings Management and Its Consequences, Contemporary Accounting Research, volume 29, issue 3, pp. 910-927

8. Jooste L., 2011. A Comparison of Ethical Perceptions of Earnings Management Practices, South African Journal of Economic and Management Sciences, volume 14, issue 4, pp. 422 435

9. Leuz C., Nanda D., Wysocki P. D., 2003. Earnings management and investor protection. An international comparison. Journal of Financial Economics, volume 69, pp. 505-527

10. Lev B. and Thiagarajan S. R.. 1993. "Fundamental Information Analysis." Journal of Accounting Research, vol. 31, no. 2 (Autumn):190-215

11. Merchant K.A., Rockness J., 1994. The Ethics of Managing Earnings: An Empirical Investigation, Journal of Accounting and Public Policy, volume 13, pp. 79-94 
12. Rest J., 1986. Moral Development: Advances in Research and Theory, Praeger, New York

13. Rosenzweig K., Fischer M., 1994. Is Managing Earnings Ethically Acceptable?, Management Accounting, volume 75, issue 9, pp. 31-34

14. Trompeter G., Carpenter T., Desai N, Jones K., Riley R., 2013. A Synthesis of FraudRelated Research, Auditing - A journal of practice and theory, volume 32, pp. 287-321

15. Wesley C., Ndofor H., 2013. The Great Escape: The Unaddressed Ethical Issue of Investor Responsibility for Corporate Malfeasance, Business Ethics Quarterly, volume 23, issue 3, pp. 443-475

Annex no. 1

Mean values from previous studies using Bruns and Merchant survey (1990)

\begin{tabular}{|l|c|c|c|c|c|c|}
\hline $\begin{array}{c}\text { Earnings } \\
\text { management } \\
\text { practice no. }\end{array}$ & $\begin{array}{c}\text { Merchant and } \\
\text { Rockness } \\
\mathbf{( 1 9 9 4 )}\end{array}$ & $\begin{array}{c}\text { Rosenzweik } \\
\text { and Fisher } \\
\mathbf{( 1 9 9 4 )}\end{array}$ & $\begin{array}{c}\text { Fisher and } \\
\text { Rosenzweik } \\
\mathbf{( 1 9 9 5 )}\end{array}$ & $\begin{array}{c}\text { Clikeman } \\
\text { et al., } \\
\mathbf{( 2 0 0 1 )}\end{array}$ & $\begin{array}{c}\text { Jooste } \\
\mathbf{( 2 0 1 1 )}\end{array}$ & $\begin{array}{c}\text { Prior } \\
\text { studies }\end{array}$ \\
\hline 1 & 1,26 & 1,18 & 1,20 & 1,09 & 1,87 & 1,32 \\
\hline 2 & 1,81 & 1,62 & 1,98 & 2,81 & 2,98 & 2,24 \\
\hline 3 & 2,09 & 1,88 & 2,29 & 3,56 & 3,18 & 2,60 \\
\hline 4 & 3,42 & 3,29 & 3,27 & 2,96 & 3,54 & 3,30 \\
\hline 5 & 1,96 & 1,81 & 1,70 & 2,24 & 2,47 & 2,04 \\
\hline 6 & 1,31 & 1,30 & 1,42 & 2,08 & 2,19 & 1,66 \\
\hline 7 & 1,25 & 1,25 & 1,41 & 1,73 & 2,40 & 1,61 \\
\hline 8 & 3,27 & 3,27 & 2,96 & 2,76 & 2,89 & 3,03 \\
\hline 9 & 3,51 & 3,32 & 3,21 & 3,06 & 3,22 & 3,26 \\
\hline 10 & 3,59 & 3,50 & 3,11 & 2,55 & 3,00 & 3,15 \\
\hline 11 & 3,69 & 3,71 & 3,43 & 3,16 & 2,70 & 3,34 \\
\hline 12 & 3,76 & 3,24 & 2,89 & 2,76 & 3,20 & 3,17 \\
\hline 13 & 4,05 & 4,15 & 3,75 & 3,76 & 3,76 & 3,89 \\
\hline $\begin{array}{l}\text { Average } \\
\text { rating }\end{array}$ & 2,69 & 2,58 & 2,51 & 2,66 & 2,88 & 2,66 \\
\hline Sample size & 308 & 265 & 500 & 115 & 360 & - \\
\hline
\end{tabular}

